\section{NOVEL COMPOSITE OF SILVER-BACTERIAL CELLULOSE (Ag-BC) FROM SIWALAN SAP (Borassus flabellifer) AND ITS ANTIBACTERIAL ACTIVITY}

Suntinia, Anastasia Wheni Indrianingsihb*, Harjonoa

aDepartment of Chemistry, Faculty of Mathematics and Natural Sciences, Semarang State University, Central Java, Indonesia bResearch Division for Natural Product Technology, Indonesian Institute of Sciences, Gading, Playen, Gunungkidul, Yogyakarta, Indonesia, 55861
Article history

Received

31 October 2019

Received in revised form

7 October 2020

Accepted

13 October 2020

Published online

17 December 2020

*Corresponding author anas004@lipi.go.id

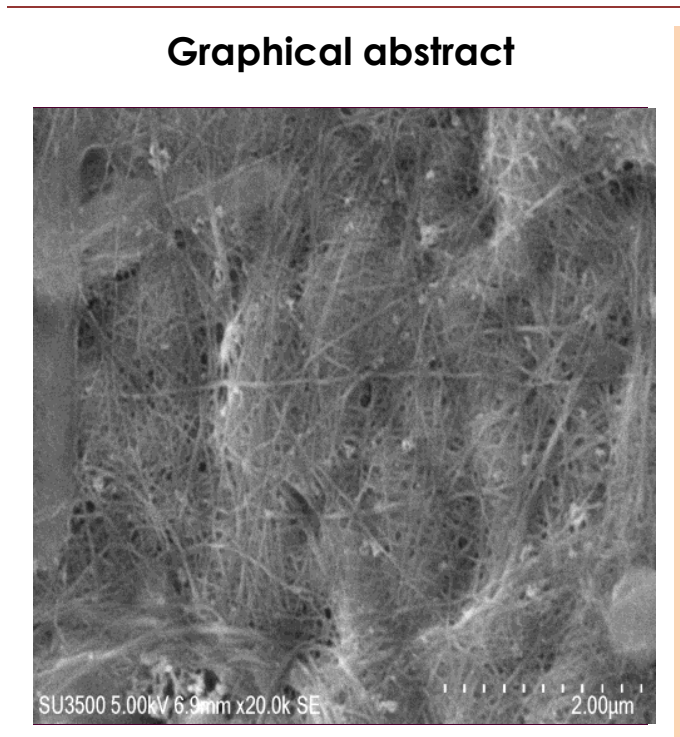

\begin{abstract}
Recently, a wound healing from natural composite with excellent properties is in a high demand. In this study, a novel composite of bacterial cellulose made from Siwalan sap (Borassus flabellifer) was achieved. Siwalan is a common plant in Java Island of Indonesia and the application is very limited for beverage only. This study aims to determine the effect of the $\mathrm{AgNO}_{3} / \mathrm{NaBH}_{4}$ concentration ratio in the development of $\mathrm{Ag}-\mathrm{BC}$ composites and its antibacterial properties from Siwalan sap. Ag-BC composites were prepared by impregnating the silver solution into the $B C$ matrix through the reduction process with $\mathrm{NaBH}_{4}$. Characterization of Ag-BC composites conducted using Fourier Transform Infrared Spectroscopy (FTIR), Scanning Electron Microscopy (SEM), and Energy Dispersive X-ray (EDX). Antibacterial assay was performed using disc diffusion method against Salmonella typhimurium (Gram-negative) and Staphylococcus aureus (Gram-positive) bacteria. The characterization of Ag-BC composite shows the nanostructure of $B C$ with a length of fiber around $35-60 \mathrm{~nm}$ in width. The SEM-EDX micrograph showed that silver particles were impregnated into the $\mathrm{BC}$ matrix. Antibacterial activity test results showed that the Ag-BC composite had the ability to inhibit the bacteria S. typhimurium and S. aureus with good inhibition. This result showed the potential application of Ag-BC composite from Siwalan plant as a natural material for medical and pharmaceutical purpose, especially as an antibacterial agent.
\end{abstract}

Keywords: Bacterial cellulose, silver, composite, antibacterial activity, Borassus flabellifer

(C) 2021 Penerbit UTM Press. All rights reserved

\subsection{INTRODUCTION}

Silver ions and silver compounds have toxic properties in some bacteria, viruses, algae, and fungi such as silver nitrate and sulfadiazine. Some researchers reported that silver particles can attack bacterial cells causing cell damage and killing the bacteria [1-5]. Silver particles in the form of nanoparticles (AgO), oxides or in the form of ions $\left(\mathrm{Ag}^{+}\right)$have a good antibacterial ability. The smaller the particle size of silver, the higher the ability of it to kill bacteria, and because of that, the properties of silver particles are utilized in the biomedical field [68]. 
In the biomedical field, in addition to utilize silver particles, bacterial cellulose (BC) material is important as raw support material. BC is a natural polymer of extracellular polysaccharides consisting of long non-aggregate nano fibrils produced by several Gram negative bacteria such as A. xylinum [9-11]. BC is a material that has high biocompatibility properties and does not cause allergic reactions. Moreover, even though $\mathrm{BC}$ does not have antibacterial properties, it can be used as support material in biomedical field such as wound dressings for burns and ulcers, regenerative skin therapy, artificial blood vessels, and tissue engineering [12-14].

Siwalan is common plants in Java Island of Indonesia and the utilization is limited for beverage only. Siwalan sap is water that comes out of the Siwalan tree through flower stalks that are cut or tapped. Siwalan sap has a sweet taste, a little sour, and has a distinctive taste. However, it only is able to be consumed fresh for 3-4 hours only. Beyond that limit, Siwalan sap immediately can turn into wine or alcoholic drinks, which have a bitter taste and can be intoxicating because it has high alcohol content [15]. The composition contained in Siwalan sap is $85.7 \%$ water; $0.38 \%$ protein; $14.38 \%$ sucrose; $0.1 \%$ fat; $0.27 \%$ ash material. Sucrose levels of Siwalan sap is high enough so that Siwalan sap can be used as a biocellulose material as it is without the addition of sugar.

Since Indonesia has a lot of Siwalan sap in an abundant amount, this research focuses on overcoming the problem of Siwalan sap' shelf life by converting it as a raw material for producing BC. To date, there has been a number of researches that study Siwalan sap as bacterial cellulose. To our knowledge, this was the first study on impregnation of silver ion to $B C$ cellulose from Siwalan sap to evaluate its antibacterial properties. The purpose of this study was to produce novel composite of Ag-BC from Siwalan sap and characterize it. The antibacterial activity was performed as it would be potentially applicable as wound dressing in the fields of biomedical or pharmaceutical.

\subsection{METHODOLOGY}

\subsection{Materials}

The materials used in this study were Siwalan sap obtained from Tuban district, East Java province, Indonesia. $\mathrm{NaBH}_{4}, \mathrm{AgNO}_{3}$, and Nutrient Broth (NB), Nutrient Agar (NA), and $\mathrm{NaCl}$ were from SigmaAldrich. Acetobacter xylinum FNCC 001, Stapylococcus aureus FNCC 0047, and Salmonella typhimurium FNCC 0165 were obtained from PAU Laboratory, Gadjah Mada University, Yogyakarta, Indonesia.

\subsection{Media Culture and BC Production}

The $\mathrm{BC}$ production referred to the research of Almeida et al. (2014); Indrianingsih et al. (2017) [16, 17a] with little modifications. The media consisted of $200 \mathrm{ml}$ of Siwalan sap with the addition of 1 gram of urea. The $\mathrm{pH}$ of Siwalan sap was 4.5 so it does not need $\mathrm{pH}$ adjustment for $\mathrm{A}$. xylinum to grow. The sap media was sterilized at $121^{\circ} \mathrm{C}$ temperature using autoclave for 15 minutes. BC production was carried out by adding $10 \%$ of the Acetobacter xylinum inoculum into each petri dish that has been filled with $10 \mathrm{ml}$ of Siwalan sap media. The mixture was then incubated at room temperature for 4-5 days to form $\mathrm{BC}$ pellicles. The resulting $\mathrm{BC}$ was then harvested and boiled in distilled water for 60 minutes and rinsed in running water until $\mathrm{pH}$ neutral. The drying process of BC was conducted at room temperature for 24 hours.

\subsection{Impregnation of Silver into Biocellulose}

The impregnation of silver ions into $\mathrm{BC}$ pellicles were conducted by immersing $B C$ into silver solution with several concentrations $\left(10^{-4} \mathrm{M} ; 10^{-3} \mathrm{M} ; 10^{-2} \mathrm{M}\right)$ for 90 minutes and then, washed with $96 \%$ ethanol for 30 seconds in order to remove the remnants of nitrate compounds. The mixture was added to $\mathrm{NaBH}_{4}$ solution for 10 minutes and then, washed again with distilled water for 10 minutes. The variation of $\mathrm{AgNO}_{3} / \mathrm{NaBH}_{4}$ ratio was 1:5; 1:50; and 1:500. It was dried for 24 hours at room temperature (approximately $28-30^{\circ} \mathrm{C}$ ).

\subsection{Characterization of Pure BC and Ag-BC Composite}

Characterization of pure $\mathrm{BC}$ and $\mathrm{Ag}-\mathrm{BC}$ composites was conducted using FTIR and SEM-EDX. The morphological structure of pure $B C$ and $A g-B C$ composites were examined on Scanning Electron Microscope SEM (SU-3500 Hitachi). The acceleration voltage of work was operating at $15 \mathrm{kV}$ with a magnification of 10,000 . FTIR spectra to evaluate the functional groups of pure BC and Ag-BC composites were recorded on 8201PC Shimadzu, Japan at a frequency range of $4000-400 \mathrm{~cm}^{-1}$ with resolution of 4 $\mathrm{cm}$ and 32 scans for each sample.

\subsection{Swelling Measurement}

This swelling percentage of Ag-BC was determined using method by Maneerung et al. (2007) and Indrianingsih et al. (2017) [11, 17a] with little modifications. Ag-BC composites and pure BC as a control medium were cut into a size of $0.5 \mathrm{~cm} \times 0.5$ $\mathrm{cm}$ in length and immersed in the distilled water for 3 days or 72 hours. Swelling capacity was calculated as follows: 
Swelling $=((G s-G i)) / G i$

where $\mathrm{Gi}$ is the initial weight of dried sample and $\mathrm{Gs}$ is the weight of sample in swollen state.

\subsection{Antibacterial Assay}

The antibacterial activity test was carried out by disc diffusion method with slight modification from the literatures [11, 12,17a, 18]. The Ag-BC composite where cut in a circle shape with a diameter of \pm 10 $\mathrm{mm}$, then it was sterilized using an autoclave at $121^{\circ} \mathrm{C}$ for 15 minutes. Ag-BC composite was placed on the NA surface in a petri disk filled with $100 \mu \mathrm{L}$ suspensions of pathogenic bacteria (S. aureus, $S$. typhimurium) with concentration of $0.9 \times 10^{9} \mathrm{CFU} / \mathrm{ml}$ and then, the media were incubated at $37^{\circ} \mathrm{C}$ for 24 hours. The inhibitory activity of Ag-BC was confirmed by measuring the clear zone formed around the AgBC composite.

\subsection{RESULTS AND DISCUSSION}

\subsection{Physical Appearance of Pure BC and Ag-BC Composites from Siwalan Sap}

BC was produced from Siwalan sap taken from the Tuban area, East Java. The resulted BC with a diameter $9 \mathrm{~cm}$ had an average weight of $12.4 \mathrm{~g}$ and has a thickness of $1.8 \mathrm{~mm}$. The water content of $\mathrm{BC}$ was $95.03 \%$. The image of pure BC and Ag-BC composites produced from Siwalan sap can be seen in Figure 1. a.

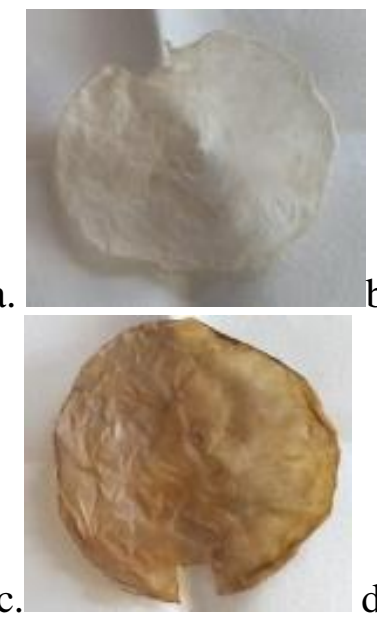

the BC microfibrils probably by ionic bonds. The presence of hydroxyl groups in BC made electronrich oxygen atoms interact with $\mathrm{Ag}$ ion. The presence of ether groups in $\mathrm{BC}$ was expected to interact with electropositive transition metal cations or $\mathrm{Ag}^{+}[11,13$, 19]. The rinsing process of $A g-B C$ with ethanol could remove $\mathrm{Ag}^{+}$which was not bound to the $\mathrm{BC}$ matrix. After the reduction process with $0.05 \mathrm{M}$ of $\mathrm{NaBH}_{4}$ silver ions are reduced to form Ag-BC composites. After the Ag reduction process, it would turn to black brown and yellow brown. The brownish yellow color indicated the formation of Ag-BC composites. After the reduction process, $A g-B C$ was dried at room temperature.

\subsection{Surface Morphology of Pure BC and Ag-BC Composites from Siwalan Sap}

The morphological surface characterization using SEM of the pure BC pellicles showed that BC consisted of nanofibrils and formed a porous structure as shown in Figure 2. The 20-50 nm nanometer-sized fibers were interconnected to form a porous structure like finely woven. Figure 2 showed the presence of bacterial cells from $B C$ in the matrix. Bacterial surfaces consist of many strings bound together to produce an aggregate structure.
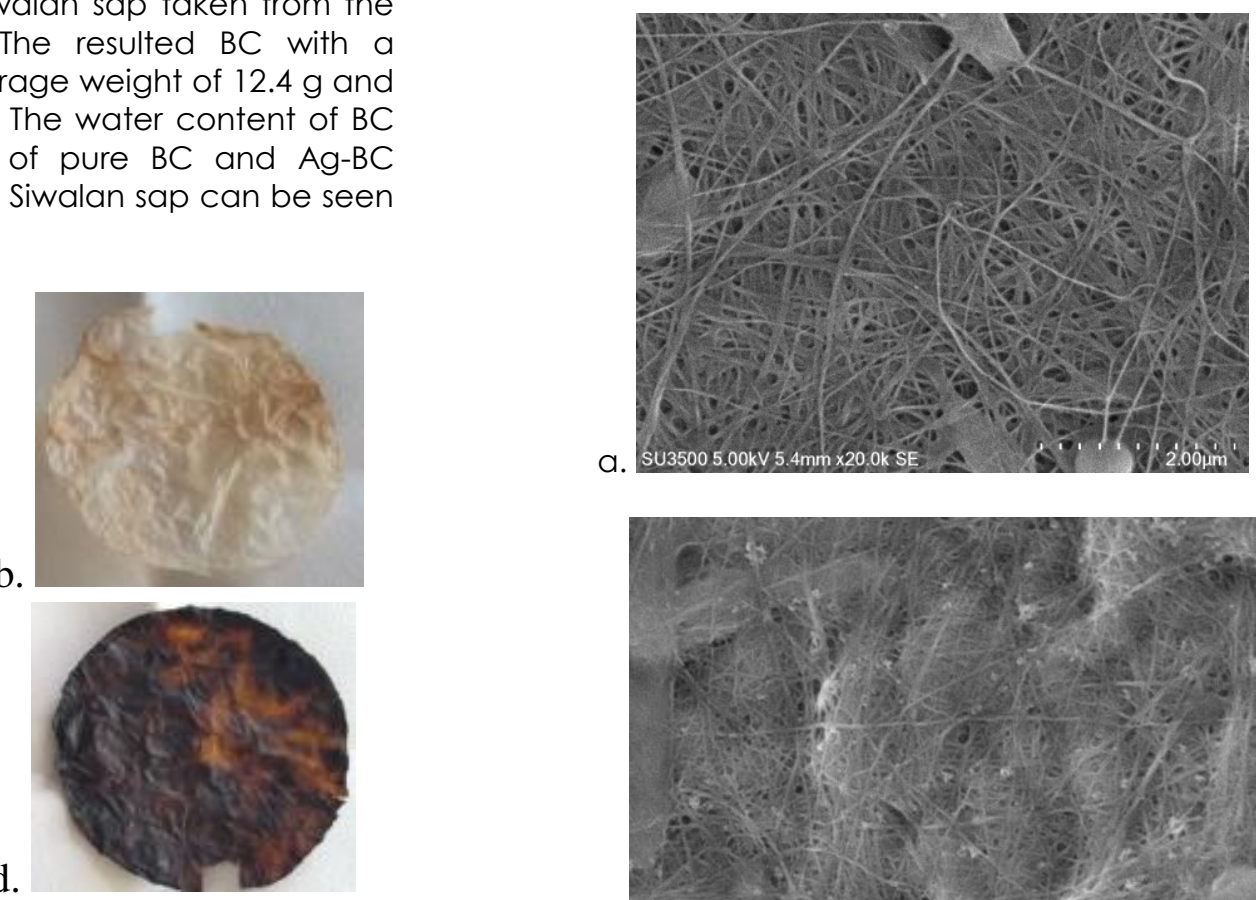

Figure $1 \mathrm{BC}$ pellicles from Siwalan sap (a) pure BC, (b) AgBC composite with $\mathrm{AgNO}_{3} / \mathrm{NaBH}_{4} 1: 500$, (c) $\mathrm{Ag}-\mathrm{BC}$ composite with $\mathrm{AgNO}_{3} / \mathrm{NaBH}_{4}$ 1:50, (d) Ag-BC composite with $\mathrm{AgNO}_{3} / \mathrm{NaBH}_{4}$ 1:5

The process of impregnation of silver particles in the $\mathrm{BC}$ matrix was by penetrating of silver ions into the biocellulose matrix through the pores. $\mathrm{Ag}^{+}$was absorbed by the matrix and was bound to the part of

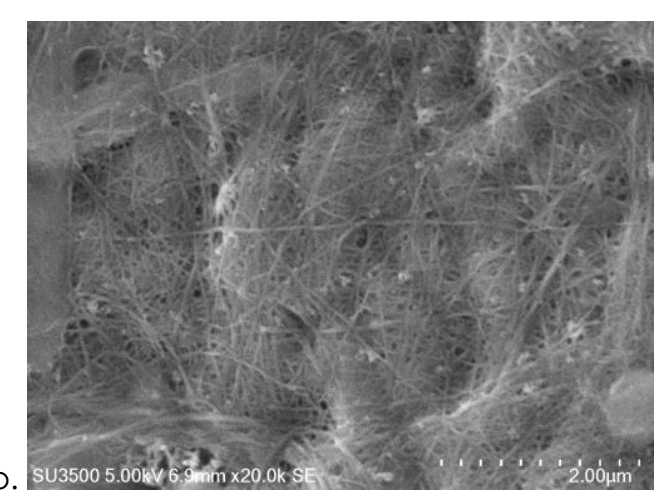




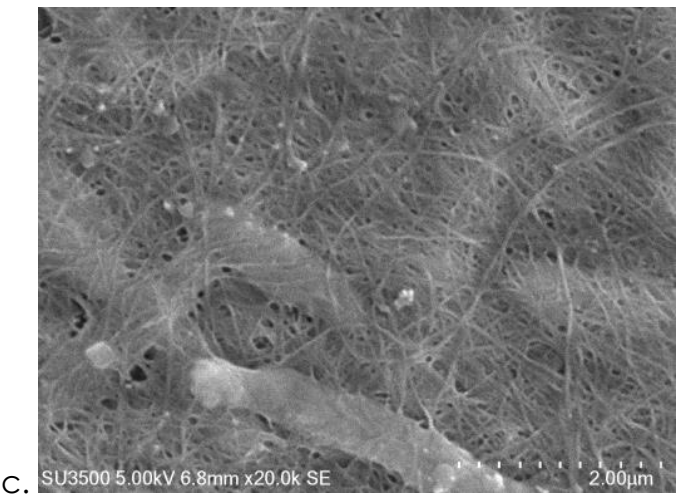

d.

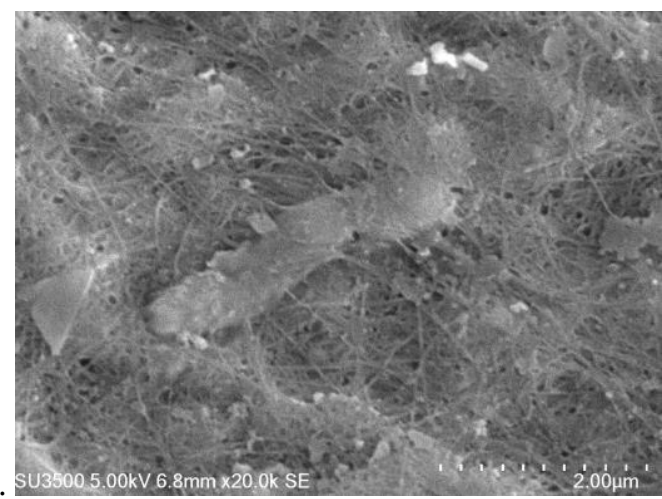

Figure 2 SEM photographs of (a) pure $B C$, (b) $A g-B C$ composite with $\mathrm{AgNO}_{3} / \mathrm{NaBH}_{4}$ 1:500, (c) $\mathrm{Ag}-\mathrm{BC}$ composite with $\mathrm{AgNO}_{3} / \mathrm{NaBH}_{4}$ 1:50, (d) $\mathrm{Ag}-\mathrm{BC}$ composite with $\mathrm{AgNO}_{3} / \mathrm{NaBH}_{4}$ 1:5

The surfaces of BC structure composed of many intertwined string neat fibrils. The results of BC studies of Siwalan sap were in accordance with existing $B C$ studies, such as literatures that reporting fine fibrils that overlap one another as layers as of cellulose tape [17b, 20].

Figure 2 (b-d) shows Ag-BC composite morphology. The results of the analysis of $\mathrm{BC}$ impregnated with silver particles with different molarity ratios of $\mathrm{AgNO}_{3} / \mathrm{NaBH}_{4}$ were seen by the deposition of silver particles in the $\mathrm{BC}$ matrix. Agglomeration occurs because silver particles accumulate during the impregnation process causing the shape and size of silver particles to differ. Agglomeration causes silver particles to lose properties related to nano size. The degree of agglomeration becomes an important parameter in toxicology tests [21]. This possibly influences the antibacterial activity test in which the Ag-BC composite has not yet been optimized in inhibiting the bacteria $S$. aureus and S. typhimurium. From the results of the analysis of Figure 2, it can be concluded that the morphology of $\mathrm{BC}$ before being impregnated with silver is very different. The results of the previous study revealed several key factors that determine the structure of $\mathrm{Ag}-\mathrm{BC}$ composites such as Ag particle size, Ag concentration in $\mathrm{Ag}-\mathrm{BC}$, the method used to produce silver nanoparticles, and techniques for inserting silver nanoparticles into the $B C$ film [22]. EDX analysis is also needed in research to determine the composition of $\mathrm{Ag}-\mathrm{BC}$ composites.

EDX analysis of the sample of pure $B C$ and $A g-B C$ composites from Siwalan sap was conducted to determine the composition of its chemical elements. The results of the EDX analysis were presented in Table 1. It was observed that the microstructure of pure $B C$ from the Siwalan sap contains $C$ and $O$. This was because the structure of $\mathrm{BC}$ consisted of glucose monomers that form chains with other glucose through glycoside bonds (1,4 D-glucopyranose anhydride) which had intra-molecular and intermolecular hydrogen bonds and van deer Waals bonds.

Table 1 Result analysis SEM-EDX of pure BC and composite Ag-BC

\begin{tabular}{cccccc}
\hline Molar ratio & \multicolumn{5}{c}{ Element (\%) } \\
\cline { 2 - 6 } AgNO $_{3}: \mathrm{NaBH}_{4}$ & $\mathbf{C}$ & $\mathbf{0}$ & $\mathbf{N a}$ & $\mathbf{A g}$ & Total \\
\hline $0: 0$ & 47.26 & 52.74 & - & - & 100 \\
$1: 500$ & 47.67 & 50.34 & 1.99 & - & 100 \\
$1: 50$ & 49.2 & 42.22 & 6.13 & 2.45 & 100 \\
$1: 5$ & 45.54 & 47.34 & 3.64 & 3.48 & 100 \\
\hline
\end{tabular}

The results of SEM-EDX analysis on $\mathrm{Ag}-\mathrm{BC}$ composite samples indicated that the impregnation process did not occur perfectly. In Ag-BC composite with $\mathrm{AgNO}_{3} / \mathrm{NaBH}_{4}$ ratio of 1:500, the silver particles were not detected on the EDX measurements. However, there was a physical change of colour (Figure 1b). It was an indication that small amount of silver is attached; however, for the reason of the limited detection of the instruments, it was not detected. That happened because when immersing BC into silver solution, silver ions were unable to penetrate the $\mathrm{BC}$ membrane so that at the stage of washing with $96 \%$ ethanol solution the silver particles were lost, and the reduction process was not optimal. The reducing agent $\mathrm{NaBH}_{4}$ would release $\mathrm{Na}^{+}$and would stick to the BC membrane. The amount of reducing agent concentration also affected the formation of silver particles.

\subsection{FTIR Characterization of Pure BC and Ag-BC Composites}

The results of the FTIR characterization of pure $B C$ and Ag-BC composites from Siwalan sap were presented in Figure 3. 


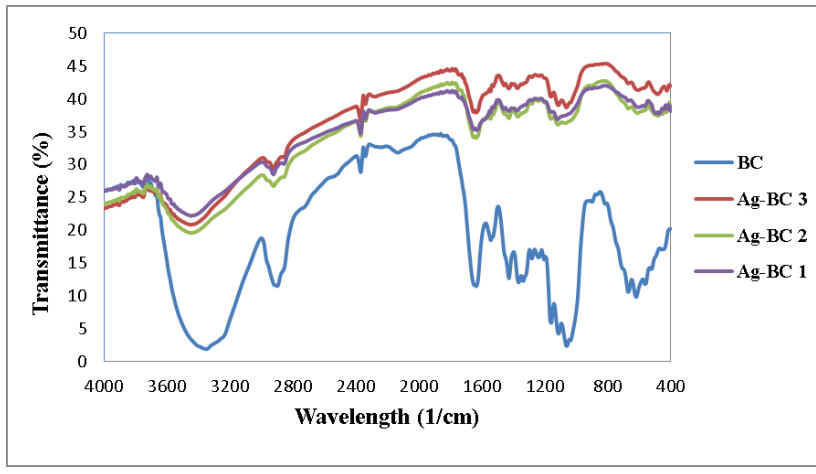

Figure 3 FTIR Spectra of pure $B C$ and $A g-B C$ composites from Siwalan sap

In pure $\mathrm{BC}$, it is known that the absorption of $\mathrm{O}-\mathrm{H}$ groups at number $3348.42 \mathrm{~cm}^{-1}$ and the $\mathrm{C}-\mathrm{O}-\mathrm{C}$ group at a wavelength of $1056.99 \mathrm{~cm}^{-1}$ shows the presence of glycoside bonds and $\mathrm{C}-\mathrm{O}-\mathrm{C}$ in the cellulose ring. At a wavelength of $2900.94 \mathrm{~cm}^{-1}$ there is a $\mathrm{C}-\mathrm{H}$ stretching and $1427.32 \mathrm{~cm}-1$ there is a bending $\mathrm{C}-\mathrm{H}$ bond. The absorption of the $\mathrm{C}=\mathrm{O}$ group is at a wavelength of $1675.64 \mathrm{~cm}-1$. All of the peak absorption of $B C$ from Siwalan sap is almost the same as $B C$, which has been produced from coconut water by literatures [20].

From the FTIR Spectra in Figure 3, in the wavelength range of $3387-3500 \mathrm{~cm}^{-1}$ there is $\mathrm{O}-\mathrm{H}$ stretching of hydroxyl groups that exist in the $\mathrm{BC}$ tissue. There is a band at a wavelength of $2877 \mathrm{~cm}^{-1}$ with vibrations of $\mathrm{C}-\mathrm{H}$ and $\mathrm{CH}_{2}$ groups. The absorption peak at $1064 \mathrm{~cm}^{-1}$ is the stretching of $\mathrm{C}-\mathrm{O}-\mathrm{C}$ groups from the $\mathrm{BC}$ matrix. In this study, $\mathrm{O}-\mathrm{H}$ group absorption occurs at a wavelength of $3348.42 \mathrm{~cm}^{-1}$ which has the most extensive area. However, in the Ag-BC composite the area of the $\mathrm{O}-\mathrm{H}$ group band was changed, this is possibly due to the presence of silver ions bound to the $\mathrm{BC}$ matrix so that the $\mathrm{O}$ group will bind to $\mathrm{Ag}^{+}$[23].

The band of $\mathrm{C}-\mathrm{H}$ groups in pure $\mathrm{BC}$ and $\mathrm{Ag}-\mathrm{BC}$ composites bears similarity at wavelengths of 2854.65 $\mathrm{cm}^{-1}$, and $2862.36 \mathrm{~cm}^{-1}$. The absorption peak at $1635.64 \mathrm{~cm}^{-1}$ is indicating the presence of the $\mathrm{C}=\mathrm{O}$ group. The absorbance of functional group observed in pure $B C$ and $A g-B C$ composites were the same as the previous studies of literatures $[23,24]$.

\subsection{Swelling Capacity}

Swelling test on $\mathrm{Ag}-\mathrm{BC}$ composites with different $\mathrm{AgNO}_{3} / \mathrm{NaBH}_{4}$ ratios in this study can be seen in Figure 4.

Capability of pure $B C$ on swelling is the highest compared to $\mathrm{Ag}-\mathrm{BC}$ composites. $\mathrm{BC}$ is a hydrophilic material which is expected to be able to absorb high amount of water. BC has three-dimensional tissue with many pores. Based on the results of the swelling it can be seen that the process of impregnation of silver into BC was successful. It means that the silver particles are bound to $B C$, thus preventing $A g-B C$ composites from absorbing more water compared to pure BC. Ag-BC composites are important ingredients in making wound dressings to maintain the level of wound moisture [17b].

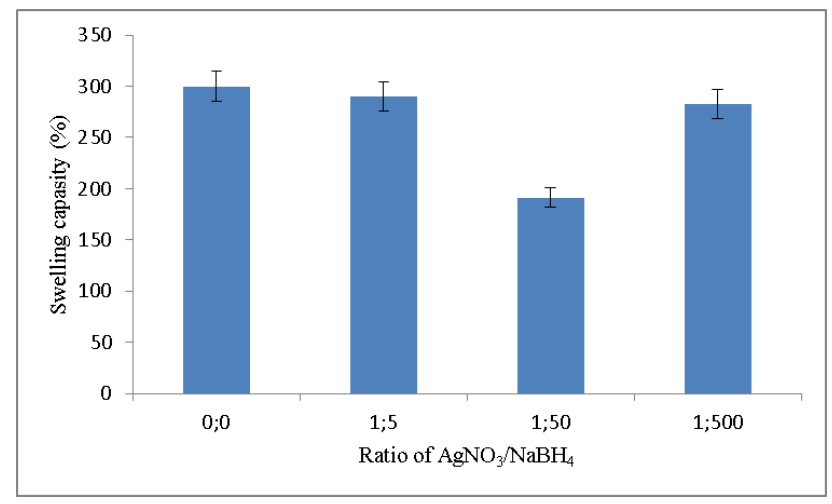

Figure 4 Swelling capability of Ag-BC composite

\subsection{Antibacterial Activity of Ag-BC Composites}

The reaction time for synthesis of $\mathrm{Ag}-\mathrm{BC}$ composites was 90 minutes of impregnation time. The results of antibacterial activity tests of $\mathrm{Ag}-\mathrm{BC}$ composites have been presented in Table 2 .

Table 2 Results of Ag-BC composite antibacterial activity test

\begin{tabular}{ccc}
\hline Ratio & \multicolumn{2}{c}{ Ag-BC composite inhibition zone (mm) } \\
\cline { 2 - 3 } AgNO $_{3}: \mathrm{NaBH}_{4}$ & $\mathbf{S}$. & $\mathbf{S}$. \\
$(\mathbf{M})$ & aureus & typhimurium \\
\hline $0: 0$ & - & - \\
$1: 5$ & 2.31 & 2.58 \\
$1: 50$ & 1.92 & 2.03 \\
$1: 500$ & - & 0.75 \\
\hline
\end{tabular}

Based on the results of antibacterial activity in Table 2 it can be concluded that Ag-BC composite can inhibit the growth of $S$. typhimurium and $S$. aureus bacteria. Pure BC (ratio 0:0) as a control sample showed no inhibition against $S$. aureus and $S$. typhimurium. The Ag-BC composite of 1:500 is only able to inhibit $S$. typhimurium. Ag-BC composites with a concentration ratio of $\mathrm{AgNO}_{3} / \mathrm{NaBH}_{4}(1: 50)$ showed the presence of silver particles impregnated on the $\mathrm{BC}$ membrane. In the Ag-BC composite of ratio 1:50 the silver concentration absorbed $2.45 \%$, while $\mathrm{Na}$ concentration absorbed $6.13 \%$. Ag-BC composites with concentration of $\mathrm{AgNO}_{3} / \mathrm{NaBH}_{4}$ ratio of $1: 5$, showed the highest inhibitory zone against $S$. aureus and $\mathrm{S}$. typhimurium. In this composite, the $\mathrm{Ag}^{+}$ concentration absorbed $3.48 \%$, while $\mathrm{Na}^{+}$as much as $3.64 \%$. Because the concentration of $\mathrm{Ag}^{+}$absorbed in $\mathrm{BC}$ is lower than the concentration of $\mathrm{Na}^{+}$, a cation concentration gradient occurs, $\mathrm{Na}^{+}$will penetrate into the $\mathrm{BC}$, and $\mathrm{Ag}^{+}$does not penetrate out [11, 17b]. 


\subsection{CONCLUSION}

Ag-BC composites from Siwalan sap had been made with various molarity ratios and had good swelling ability and antibacterial activity. The higher the concentration of silver particles, the higher the chance of formation of aggregation in particles. The ratio of $\mathrm{AgNO}_{3} / \mathrm{NaBH}_{4}$ in $\mathrm{Ag}-\mathrm{BC}$ composite which has the ability of antibacterial activity is $(1: 5)$ and $(1: 50)$. Antibacterial activity test results showed that the Ag$B C$ composite had the ability to inhibit the bacteria $S$. typhimurium and $S$. aureus with good inhibition. This result showed the potential application of $\mathrm{Ag}-\mathrm{BC}$ composite from Siwalan plant as a natural material for medical and pharmaceutical purpose, especially as an antibacterial wound dressing.

\section{Acknowledgement}

This research was supported by Insinas research grant from Indonesian Ministry of Technology in 2017 andpartly from PRN project No 149/El/PRN/2020 from Indonesian Ministry of Technology in 2020.

\section{References}

[1] Morones, J. R., Elechiguerra, J. L., Camacho, A., Holt, K., Kouri, J. B., Ramırez, J. T., Yacaman, M J. 2005. The Bactericidal Effect of Silver Nanoparticles. Nanotechnology. 16: 2346.

[2] Lok, C. N., Ho, C. M., Chen, R., He, Q. Y., Yu, W. Y., Sun, H., Tam, P. K., Chiu, J. F. \& Che C. M. 2006. Proteomic Analysis of the Mode of Antibacterial Action of Silver Nanoparticles. Journal Proteome Res. 5: 916-924.

[3] Yang, W., Shen, C., Ji, Q., An, H., Wang, J., Liu, Q. \& Zhang, Z. 2009. Food Storage Material Silver Nanoparticles Interfere with DNA Replication Fidelity and Bind with DNA. Nanotechnology. 20: 0957-4484.

[4] Chaloupka, K., Malam, Y. \& Seifalian, A. M. 2010. Nanosilver as a New Generation of Nanoproduct in Biomedical Applications. Journal Trends Biotechno. 28: 580-588.

[5] XU, Q., Li, R., Shen, L., XU, W., Wang, J., Jiang, Q., Zhang, L., Fu, F., Fu, Y., Liu, X. 2019. Enhancing the Surface Affinity with Silver Nano-particles for Antibacterial Cotton Fabric by Coating Carboxymethyl Chitosan and I-cysteine. Appl. Surf. Sci. 497: 143673. DOI: https://doi.org/10.1016/j.apsusc.2019.143673.

[6] Prasad, S. B. 2013. Current Understanding of Synthesis and Pharmacological Aspects of Silver Nanoparticles. American Journal of Phytomedicine and Clinical Therapeutics. 1 (7): 536-547.

[7] Sanjivkumar, M., Vaishnavi, R., Neelakannan, M., Kannan, D., Silambarasan, T., Immanuel, G. 2019. Investigation on Characterization and Biomedical Properties of Silver Nanoparticles Synthesized by an Actinobacterium Streptomyces Olivaceus (MSU3). Biocatal. Agric. Biotechnol. 17: 151-159. https://doi.org/10.1016/j.bcab.2018.11.014.

[8] Xu, J., Zhu, X., Zhou, X., Khusbu, F. Y., Ma, C. 2020. Recent Advances in the Bioanalytical and Biomedical Applications of DNA-templated Silver Nanocluster. TRAC Trend Anal Chem. 124: 115786.

[9] Brown, R. M., Willson, J. H., Richardson, C. L. 1976. Cellulose Biosynthesis in Acetobacter xylinum: Visualization of the Site of Synthesis and Direct Measurement of the in Vivo
Proses. Proceedings of the National Academy of sciences of the United States of America. 73(12): 4565-4569.

[10] Kurosumi, A., Sasaki, C., Yamashita, Nakamura, Y. 2009. Utilization of Various Fruit Juice as Carbon Source for Production of Bacterial Cellulose by Acetobacter xylinum NBRC 13693. Carbohydrate Polymer. 76(2): 333-335.

[11] Maneerung, T., Tokura, S., Rujiravanit, R. 2007. Impregnation of Silver Nanoparticles into Bacterial Cellulose for Antimicrobial Wound Dressing. Carbohydrate Polymers. 72: 43-51

[12] Wu, J., Zheng, Y., Song, W., Luan, J., Wen, X., Wu, Z., Chen, X., Wang, Q., Guo, S., 2013. In situ Synthesis of Silvernanoparticles/bacterial Cellulose Composites for Slow released Antimicrobial Wound Dressing. Carbohydrate Polymers.

[13] Pal, S., Nisi, R., Stoppa, M., Licciulli, A. 2017. SilverFunctionalized Bacterial Cellulose as Antibacterial Membrane for Wound-healing Applications. American Journal Chemical Sociaty. 2: 3632-3639.

[14] Zhang, Z. Y., Sun, Y., Zheng, Y. D., He, W., Yang, Y. Y., Xie, Y. J., Feng, Z. X., Qiao, K. 2020. A Biocompatible Bacterial Cellulose/Tannic Acid Composite with Antibacterial and Anti-biofilm Activities for Biomedical Applications. Mater. Sci. Eng. C. 106: 110249.

[15] Mardiyah, S. 2017. Pengaruh Lama Pemanasan Terhadap Kadar Alkohol Pada Nira Siwalan (Borassus flabellifer). The Journal of Muhamadiyah Medical Laboratory Technologist. 2(1): 99-15.

[16] Almeida, I. F., Pereira, T., Silva, N. H. C. S., Gomes, F. P. Silvestre, A, J. D., Freire, C. S. R., Sousa Lobo, J. M., and Costa, P. C. 2014 Bacterial Cellulose Membranes as Drug Delivery Systems: An in Vivo Skin Compatibility Study Eur. J. Pharm. Biopharm. 86: 332-336

[17] andrianingsih, W., Rosyida, V. T., Jatmiko, T. H., Prasetyo, D. J., Poeloengsih, C. D., Apriyana, W., Nisa, K., Nurhayati, S., Hermawan, Darsih, C., Pratiwi, D., Suwanto, A., Ratih, D., 2017. Premilinary Study on Biosynthesis and Characterization of Bacteria Cellulose Films from Coconut Water. IOP Conf. Series: Earth and Enviromental Science. doi:10.1088/1755-1315/101/1/012010.

blndrianingsih, A. W., Maryana, R., Rosyida, V. T., Apriyana W., Jatmiko, T. H., Hayati, S. N. 2017. Antibacterial Activity of Silver-modified Bacterial Cellulose Produced from Coconut Water for Wound Dressing Application. Chemistry Research Journal. 2(6): 251-261.

[18] Shidlovskiy, I. P., Shumilova, A. A., dan Shishatskaya, E. I., 2017. Preparation and Caracterization of Bacterial Cellulose Composites with Silver Nanoparticles. Journal of Siberian Federal University. Biologi. 10(2): 255-264.

[19] He, J., Kunitake, T., dan Nakao, A. 2003. Facile In Situ Synthesis of Noble Metal Nanoparticles in Porous Cellulose Fibers. Chemistry of Materials. 15: 4401-4406.

[20] Halib, N., Amin, M. C. I. M., dan Ahmad, I. 2012. Physicochemical Properties and Characterization of Nata De Coco from Local Food Industries a Source of Cellulose. Sains Malaysiana. 41 (2): 205-211.

[21] Lee, G. J dan Y. P. Lee. 2008. Microstructures and Linear/ Nonlinear Optical Properties of Monolayered Silver Nanoparticles. Journal of the Korean Physical Society. 53(6): 3818-3820.

[22] Volova, T. G., Shumilova, A. A., Shidlovskiy, I. P., Nikolaeva, E. D. 2018. Antibacterial Properties of Film of Cellulose Composites with Silver Nanoparticles and Antibiotics. Polymer Testingi. 65: 54-68.

[23] Salasa, D., Aritonang, H., Kamu, V. S. 2016. Sintesis Nanopartikel Perak (Ag) dengan Reduktor Natrium Borohidrat $\left(\mathrm{NaBH}_{4}\right)$ Menggunakan Matriks Nata de coco. Chem. Prog. 9(2): 40-47. DOI: https://doi.org/10.35799/cp.9.2.2016.27984.

[24] Mohite, Bhavana \& Patil, Satis V. 2016. In situ Development of Nanosilver-impregnated Bacterial Cellulose for Sustainable Released Antimicrobial Wound Dressing. Biomater Funct Mater. 14(1): 53-58. 